\title{
Origami Tabanlı Öğretim Uygulamalarının Öğretmen Adaylarına Katkıları ve Karşılaşılan Zorluklar: Üçgen ve Dörtgenler
}

DOI: $10.26466 /$ opus.651290

$*$

\author{
Mihriban Hacısalihoğlu Karadeniz * \\ * Doç. Dr., Giresun Üniversitesi, Eğitim Fakültesi, Matematik ve Fen Bilimleri Eğitimi Bölümü, \\ Giresun/Türkiye \\ E-Posta: mihrideniz61@gmail.com \\ ORCID: $\underline{0000-0002-7836-6868}$ \\ Öz
}

Bu çalışmanın amacı, "Üçgen ve Dörtgenler" konusunun origami tabanlı etkinliklerle uygulanması sürecinde öğretmen adaylarının karşılaştıkları zorlukları ve sağladığı katkıları ortaya koymaktır. Açıklayıcı durum çalışması ile yürütülen araştırmanın çalışma grubunu Doğu Karadeniz Bölgesinde yer alan bir devlet üniversitesinin Eğitim Fakültesi Matematik Öğretmenliği Anabilim Dalında öğrenim gören 38 öğretmen adayı oluşturmuştur. Veriler, araştırmacı tarafından hazırlanan açık uçlu sorulardan oluşan "Öğretmen Adaylarına İlişkin Görüşme Formu" ve adayların hazırladıkları "Klasik Origami Raporu" kullanılarak toplanmıştır. Katılımciların, origami yaptırma ve uygulama, sınıf kontrolünü sağlama ve geometri öğretmede birtakım zorluklar yaşadıkları bulgulardan elde edilen sonuçlar arasındadır. Origami tabanlı öğretim uygulamalarının öğrencilere; programdaki kazanımları ve geometriyi daha iyi ve eğlenerek öğrenmeye, merak etmeye, ilgi ve dikkaterini çekmeye katkı sağladı̆̆ın göstermiştir. Origami tabanlı öğretim uygulamalarının öğretmen adaylarına katkıları ise mesleki ve kişisel deneyim kazanma olarak açı̆̆a çıkmıştır. Bu çalışma ile "Kâ̆̆̆t Katlama Yöntemi ile Matematik" ya da "Origami" seçmeli dersinin "İlköğretim Matematik Öğretmenliği Lisans Programı"na yeniden yerleştirilmesi yoluna gidilebilir. Bu çalışma öğrencilerin, öğretmen adaylarının ve öğretmenlerin çeşitli konulardaki öğretim uygulamalarını zenginleştirmek adına origami etkinlikleriyle yapılandırılan sınıf ortamları tasarlamalarına rehberlik edebilir. Son olarak; mevcut çalışma ile "Origami" dersinin ilkokul, ortaokul ve ortaöğretim programlarına yerleştirilmesi yönünde de dikkat çekmesi umulmaktadir.

Anahtar Kelimeler: Origami tabanlı öğretim uygulamaları, üçgen ve dörtgenler, matematik dersi öğretim programı, matematik öğretmeni adayları, ortaokul öğrencileri 


\title{
Contributions and Challenges of Origami Based Teaching Practices to Prospective Teachers: Triangle and Quadrangles
}

\begin{abstract}
The purpose of the study is to reveal the contributions and challenges of applying "Triangle and Quadrangles" with origami based activities to teacher candidates in the process. The study group of the research conducted with the explanatory case study consisted of 38 pre-service teachers studying at the Department of Mathematics Education at the Faculty of Education of a public university in the Eastern Black Sea Region. The data were collected by using the "Interview Form for Teacher Candidates" consisting of open-ended questions prepared by the researcher and the "Classic Origami Report" prepared by the candidates. It is among the results obtained from the findings that the participants experienced some difficulties in making and practicing origami, maintaining classroom control and teaching geometry. Origami based teaching applications to students; It has shown that it contributes to learning, wondering, attracting attention and attention by gaining and gaining geometry better and fun. The contribution of origami based teaching practices to prospective teachers was revealed as gaining professional and personal experience. With this study, it is possible to relocate the "Mathematics by Paper Folding Method" or "Origami" elective course to "Primary Mathematics Teaching Undergraduate Program". This study can guide students, prospective teachers and teachers to design classroom environments structured with origami activities in order to enrich their teaching practices on various topics. Finally; With the current study, it is hoped that the "Origami" course will draw attention to the placement of primary, secondary and secondary education programs.
\end{abstract}

Keywords: Origami teaching practices, triangle and quadrangles, mathematics curriculum, prospective mathematics teachers, middle school students 


\section{Giriş}

"Katlanmış kâğıt" anlamına gelen origami, Japonya'da uzun yıllardır ilkokulların ders programına alınmış, Japonların geleneksel sanatı olmaktan öteye pek çok ülkede her yaş grubunun ilgilendiği bir uğraş ve birçok eğitim kurumunda kullanılan öğrenmeyi öğretme aracı hâline gelmiştir (Milli Eğitim Bakanlığı [MEB], 2011). Türkiye'de de origami ya da kâğıt katlama uygulamalarının; ilköğretim matematik, ortaokul matematik ve ortaöğretim geometri dersi öğretim programlarında kullanılmasına vurgu yapıldığı görülmektedir (MEB, 2008, 2009, 2011, 2013a, 2018).

Origami olarak bilinen kâğıt katlama işi, tek bir kâğıdın katlanması ile ya da birden çok kâğıdın katlanıp birbirine geçirilmesiyle ile de yapılabilir (Aslan, 2012; Arslan, Işıksal-Bostan ve Şahin, 2013; Tuğrul ve Kavici, 2002). Kâğıt katlayarak; geometrik şekiller, matematiksel ilişkiler, desenler oluşturma önem kazanmakta ve anlamlı öğrenme için yeni firsatlar sunmaktadır (MEB, 2013). Dolayısıyla kullanılan bu etkinliklerle öğrencilerin davranışsal etkilerinde, psiko-motor gelişiminde, sosyal ve duyuşsal ve dil alanı gelişiminde, matematik eğitiminde yardımcı araç olması, kavramları somut bir şekilde öğrenilmesinde pek çok faydası olduğu vurgulanmaktadır (Coad, 2006; Mastin, 2007; MEB, 2011). Origaminin bu fayda ve etkileri dışında; kanıt yapma (Georgeson, 2011), uzamsal düşünebilme (Çakmak, 2009) ve mekânsal ilişkileri görebilme (Akayuure, Asiedu-Addo ve Alebna, 2016) becerilerini geliştirmede, mekânsal görselleştirme, geometri başarısı ve geometrik akıl yürütmede (Arıcı ve Aslan-Tutak, 2015) de etkili olduğu da belirlenmiştir. Öte yandan origami tabanlı öğretim uygulamaları ile matematik öğretebilmenin yanı sıra bu etkinliklerle işlenen derslerde öğrencilerin eğlendiklerini, ilgi ve motivasyonlarının artığını (Boakes 2008; Chen, 2006; Çakmak 2009; Hacısalihoğlu Karadeniz, 2018; Polat, 2013; Sze, 2005; Tuğrul ve Kavici 2002) ve matematik dilinin gelişimine etkisi olduğunu (Cipoletti ve Wilson, 2004; Mastin, 2007) gösteren çalışmalar da mevcuttur.

Origami türlerinden klasik ve parçalı origami günümüzde modern origami olarak adlandırılarak yapıştırma ve kesme serbest bırakılmış; mimari origami, pop-up origami, krigami olarak sınıflandırılmıştır (Tuğrul ve Kavici, 2002). Klasik origamide tek parça kâğıttan çeşitli hayvan veya eşya figürleri yapılır, parçalı origami ya da modüler origamide ise birbirinin benzeri parçalar bir araya getirilerek üç boyutlu geometrik modeller oluşturulur (Tuğrul 
ve Kavici, 2002). Origami etkinlikleri ile daha çok geometri konularının öğretiminin ele alındığını söylemek mümkündür (Arıcı, 2012; Akayuure vd., 2016; Georgeson, 2011; Hacısalihoğlu Karadeniz, 2017, 2019; Boz, 2015; Craine ve Rubenstein, 1993; Çakmak, 2009; DeYoung, 2009; Duatepe-Paksu, 2016; Golan ve Jackson, 2010). Öte yandan literatürde origami etkinlikleriyle kesirler, cebir, olasılık konularının öğretimine örnek oluşturacak bazı çalışmaların mevcut olduğu da görülmektedir (Akan-Sağsöz, 2008; 2011; Akayuure vd., 2016; Arıc1, 2012; Boakes, 2008, 2009; Brady, 2008. Georgeson, 2011; Hacısalihoğlu Karadeniz, 2017, 2018; Higginson ve Colgan, 2001).

Origami etkinlikleriyle işlenen geometri derslerinde, çocukların boyut karşılaştırmalarında daha etkili stratejiler kullanılarak anlamlı ilişkilendirme yapabildikleri görülmüştür (Yuzawa ve Bart, 2002). Çakmak (2009) çalışmasında, origaminin öğrencilerin uzamsal becerilerinin artmasında origami öğretim uygulamalarının etkili olduğuna değinmiştir. Golan ve Jackson (2010) ise çalışmalarında, kullandıkları "Origametria" adlı programın öğrencilerin geometri bilgilerini geliştirdiğini, öğrencilerin derse katılımlarını artırdığını ortaya koymuştur. Wares $(2013,2016)$ de çalışmasında, origaminin geometri öğretiminde uzamsal zekâyı geliştirmek amaciyla kullanılan bir uygulama olduğundan bahsetmiştir. Duatepe-Paksu (2016) çalışmasında, kâğıt katlama yöntemiyle kenar, doğru, doğru parçası, açları, noktaları oluşturarak, araçgereç ya da teknoloji kullanmaya gerek kalmadan geometri kavramlarının öğretimine dikkat çekmiştir. Mastin (2007)'de, hikâye etkinliğinde origami kullanarak okul öncesi ve ilköğretim çağındaki çocukların matematiksel dil edinimlerini sağlayacağı gibi problem çözme becerilerini de geliştireceğine dikkat çekmiştir. Benzer biçimde Hacısalihoğlu Karadeniz (2017), kağıt katlayarak oluşturulan origamilerin öğrencilerin bilişsel gelişimine katkı sağladığını, problem çözme, uzamsal düşünme ve soyutlama yapabilme becerilerini geliştirdiğini belirlemiştir. Dolayısıyla matematik ve geometri kavramlarının anlaşılmasında origami uygulamalarının işe koşulmasının oldukça yararlı olduğu söylenebilir.

Öğretmen dersinde origamiyi matematikle doğru ilişkilendirdiği takdirde (Georgeson 2011), matematik eğitimine katkı sunan bir yöntem olabileceği düşünülmektedir (Boakes 2008). Öte yandan bu ilişkisinin kurulmadığı durumlarda bile origami, eğitim alanında kullanılması uygun yöntemlerden biridir (Boakes 2008, 2009; Chen 2006; Sze 2005; Tuğrul ve Kavici 2002). Dolay1sıyla matematik öğretiminde çeşitli yöntemler kullanılması; bazı kavram ve 
işlemlerin somutlaştırılmasına, öğrencilerin matematiği ezberlemek yerine anlayarak öğrenmelerine ve öğrencinin matematiğe ön yargısız bir şekilde yaklaşarak öz güveninin artmasına yardımcı olabilir (MEB, 2009, 2013, 2017, 2018a; NCTM, 2000). Matematik derslerinde öğrencilere nedenlerini ve birbiri ile ilişkilerini bilmedikleri kuralları ezberletmeye dayalı bir öğretim yapmaya çalışmak, öğrencilerin matematikten soğumasına, matematiği zor, gereksiz bir ders olarak algılamalarına yol açabilir. Derslerde kuralların nedenleri irdelenip, bu kuralların matematiksel kavramları ilişkilendirmesini ve bu ilişkilendirmeyi irdelemesini sağlayacak ortamlar yaratılmalıdır (Boz, 2008). Bu ortamlardan biri de, matematik derslerinde öğrencinin yaparak-yaşayarak-anlayarak öğrenmesine yardımcı olacak origami gibi etkinliklerin kullanıldığı ortamlar olabilir. Tüm bunlardan ötürü süreçte; öğrenci merkezli öğretimin yapıldığı, aktif öğrenmenin uygulandığı, somut model ve materyal destekli öğretimin yapıldığı, işbirlikli öğrenmenin uygulandığı sınıf ortamları tasarlanmalıdır (NCTM, 1989, 2000). Origami, öğrenmede görsel, dokunsal ve bedensel bir eylemi gerçekleştirdiğinden eğitim-öğretim sürecinde kullanılmasının uygun olduğu düşünülmektedir (Tuğrul ve Kavici, 2002). Buradan sınıf ortamında origami uygulamalarıyla yapılan öğretim uygulamaları; eğitim sürecinde öğrenenleri motive eder, aktif hale getirdiği için öğrenmeyi teşvik eder ve süreçte öğrenenlere yardımcı olur denilebilir (Hacısalihoğlu Karadeniz, 2017). Böylece öğrenci matematik öğrenmeyi öğrenir; öğrenmeyi öğrenme, bireyin hayat boyu öğrenmeyi başarması ve sürdürmesindeki çabası, öğrenme ihtiyaç ve süreçlerinin farkında olması ve başarılı bir öğrenme eylemi için zorluklarla başa çıkmasıdır. Daha açık olarak öğrenmeyi öğrenme; bilgi ve becerilerin ev, iş yeri, eğitim ve öğretim ortamı gibi çeşitli bağlamlarda kullanılması ve uygulanması için önceki öğrenme ve hayat tecrübelerine dayanılması yönünde öğrenenleri harekete geçirir (MEB, 2018a).

Baki'ye göre (2018), öğrenciyi tanıma, onun mevcut bilgisini işler hale getirme ve öğrenciyi merkeze alan bir öğrenme-öğretme ortamı inşa edebilme matematik öğretme bilgisinin pedagoji bilgisi kısmıdır. Dolayısıyla öğretmen adaylarının pedagoji bilgisine; matematik bilgisi ve matematiği öğretme bilgisi katılarak, bu bilgilerini güçlendirmek adına origamiyle zenginleştirilmiş öğretim uygulamalarını deneyimlemeleri yararlı olacaktır denilebilir. Süreçte origami tabanlı öğretim uygulamaları yapmanın matematiği öğretme bilgisine katkı sağlayacağı düşünüldüğünden, bu uygulamaların ilgi çekici yönlerini göstermek, ilköğretim hatta ortaöğretim programlarında yer almasına 
vesile olması hedeflenmiştir. Bu bağlamda mevcut çalışma ile öğretmen adaylarına ve öğretmenlere de sınıf içi uygulamalarında matematik ve geometri kavramların öğretmede bu yöntemi kullanmalarına ilişkin farkındalık yaratmak hedeflenmektedir. Dolayısıyla çalışmanın amac1, “Üçgen ve Dörtgenler" konusunun origami tabanlı etkinliklerle uygulanması sürecinde öğretmen adaylarına sağladığı katkıları ve karşılaştıkları zorlukları ortaya koymaktır. Bu amaç doğrultusunda aşağıdaki sorulara cevap aranmıştır:

1. Öğretmen adaylarının klasik origami tabanlı öğretim uygulamalarında karşılaştıkları zorluklar nelerdir?

2. Klasik origami tabanlı öğretim uygulamalarını öğrencilere sağladığı katkılara ilişkin öğretmen adaylarının görüşleri nelerdir?

3. Klasik origami tabanlı öğretim uygulamalarının öğretmen adaylarına sağladığ 1 katkılar nelerdir?

\section{Yöntem}

Bu çalışma, açıklayıcı durum çalışması yaklaşımı kullanılarak yürütülmüştür. Açıklayıcı durum çalışmasında daha çok araştırmanın amacı, neden ve nasıl sorularını cevaplamaya çalışmaktadır (Yin, 2009). Nitel araştırma desenlerinden açıklayıcı durum çalışması, güncel bir olguyu kendi gerçek yaşam çerçevesi içinde çalışan ve durumları çok yönlü, sistemli ve derinlemesine inceleyen bir araştırma yöntemidir (Patton, 1990; Cohen, Manion ve Morrison, 2000; Yıldırım ve Şimşek, 2013). Bu çalışmada, öğretmen adaylarına ders kapsamında geometri öğretimine yönelik çeşitli klasik origami etkinlikleri hazırlatarak; gerçek ortamda uygulamasını yaptırılması, kendilerinin ve hedef grup üzerindeki etkilerinin neler olduğunu betimlemesi ve sınırları belirli bir durumun açıkça ortaya koyulması amaçlandığından, çalışma açıklayıcı durum çalışmasıdır.

\section{Katılimcilar}

Araştırmanın katılımcılarını, amaçlı örnekleme yöntemlerinden, kolay ulaşılabilir durum örneklemesi yoluyla 2017-2018 öğretim dönemi güz yarıyılında Doğu Karadeniz bölgesinde bir devlet üniversitenin matematik öğretmenliği 2. Sınıfında "Kâğıt Katlama Yöntemi ile Matematik" dersini alan 38 öğretmen 
adayı ile yürütülmüş̧tür. Katılımcıların 32'si kız, 6'sı ise erkektir. Kolay ulaşılabilir durum örneklemesi yönteminde araştırmacı, yakın ve erişilmesi kolay olan bir durumu seçer, böylece araştırmaya hız ve pratiklik kazandırır (Yıld1rım ve Şimşek, 2013). Katılımcılar, klasik origami uygulamalarına ait bilgileri, bahsi geçen ders kapsamında almışlardır. Adayların tamamına yakınının söz konusu derste başarılı oldukları bilindiğinden, uygulamalarla ilgili gerekli bilgiye sahip oldukları kabul edilerek araştırmaya başlanmıştır. Çalışma etiği çerçevesinde katılımcıların isimleri gizli tutulmuştur. Dolayısıyla adaylar “K1, K2... K38” olarak kodlanmışlardır (K: Katılımcı öğretmen adayı).

\section{Verilerin Toplanması ve Analizi}

Çalışmada katılımcılara, "Kâğıt Katlama Yöntemi ile Matematik" dersi kapsamında çeşitli klasik origami modelleri hazırlatılmış; öğretilecek kavramlara uygun birer rapor yazmaları istenmiştir. Katılımcılar raporları tasarlarken; öğrenme alanı, alt öğrenme alanı, sınıf düzeyi, kazanımlar, yöntem/teknikler, araç-gereç/materyal ve dersin işlenişini seçmekte serbest bırakılmışlardır. Veriler, araştırmacı tarafından hazırlanan açık uçlu sorulardan oluşan "Öğretmen Adaylarına İlişkin Görüşme Formu" ve adayların hazırladıkları "Klasik Origami Raporu" kullanılarak toplanmıştır. Katılımcılardan, origami ile öğretim yapacakları konuya ilişkin tüm aşamaları ayrıntılı bir şekilde rapor etmeleri istenmiştir. Görüşme formunda ise katılımclardan, origami uygulamaları ile geometri öğretiminin sağladığı katkılara ve süreçte karşılaştıkları sorunlara yönelik cevaplar vermeleri istenmiştir.

Bu çalışmada geçerliğin sağlanması amacıyla veriler; söz konusu ders kapsamında yapılan haftalık bireysel ve grup sunumları, haftalık bireysel ve grup raporları, süreçte yapılan dönüt ve düzeltmeler, raporların eğitim ortamındaki uygulamaları gibi sürece ilişkin verilerin bulunduğu materyaller toplanmıştır. Formlardan ve raporlardan elde edilen veriler içerik analizi ile değerlendirilmiştir. Böylece araştırmacı veriler arasında bir karşılaştırma yapabilme olanağına kavuşmuştur (Yıldırım ve Şimşek, 2013). Içerik analizi yapılırken önce her bir görüşme için veriler kodlanmış, ardından sınıflamalar yapılmış ve üçüncü aşamada ise tema ve kodlar oluşturulmuş, bulgular tanımlanarak yorumlanmıştır. Tabloların yorumlanmasında katılımcılardan doğrudan alıntılar yapılarak görüşler sunulmuş ve bu görüşler değerlendirilmiştir. Veri analizinin güvenilirliğini artırmak için veriler ikinci bir uzman 
tarafından kodlanarak aralarındaki uyuma bakılmıştır. Katılımcılar bazı temalar için birden fazla görüş belirttiği ve bu görüşler ayrı ayrı frekanslar olarak alındığı için şemalardaki frekanslar toplamının katılımcı sayısından fazla olduğu görülmektedir.

\section{Origami Tabanh Öğretim Etkinliklerinin Uygulanma Süreci}

Araştırmacı tarafından katılımcılara, 2017-2018 eğitim-öğretim yılının güz döneminde ilgili derste 3 hafta boyunca, origami modelleri yaptırılmış; öğretilecek kazanımlara uygun planların hazırlatılmasına çalışılmıştır. Çalışma kapsamında tasarlanan modeller ve bunların uygulamalarının değerlendirilmesi için katılımcıların rapor hazırlamaları ve süreçte sunulması istenmiştir. Ardından araştırmacının rehberliğinde son hali verilen origami modelleri ile hazırladıkları uygulamalar/planlar katılımcılar tarafından çeşitli okullarda 4 hafta boyunca uygulanmıştır.

Katılımcılar tarafindan hazırlanan "Klasik Origami Uygulamaları Raporları" incelendiğinde; tasarlanan modellerin; “Üçgen ve Dörtgenler” konularının kazanımlarına ait uygulamaları içerdiği görülmektedir. Katılımclara hazırladıkları origami modelinin; öğrenme/alt öğrenme alanı, sınıf düzeyi, kazanımlar, yöntem/teknikler, araç-gereç/materyal ve dersin işlenişini belirlemeleri için üç haftalık süre tanınmıştır. Üç hafta sonunda katılımclar karar verdikleri modelleri ve $5 \mathrm{E}$ öğrenme modeline uygun ders planlarını sınıfta önce bireysel, ardından grup çalışması şeklinde sunmuşlardır. Her hafta yürütülen ders saati içerisinde katılımcılar ile derslerde görüşmeler yapılmış ve her bir uygulama için derste haftalık rapor yazmaları istenmiştir. Katılımcıların raporları incelenerek bir sonraki derste planların işleyişi ile ilgili geri bildirimler verilmiştir. Uyarlamalar tamamlandıktan sonra dönemin son haftalarına doğru sınıfta bireysel sunum yapılmıştır. Katılımcılardan uygulama sürecini fotoğraflar ile kayıt altına almaları ve uygulamaların ders döneminin bitmesine iki hafta kala tamamlamaları istenmiştir. Örnek teşkil etmesi aç1sından birbirinden farklı iki tane $5 \mathrm{E}$ öğrenme modeline uygun ders planının uygulama süreci aşağıda sunulmuştur:

\section{Dinozor Modeli Raporu}

Sinı dïzeyi: 5. Sinıf 
Öğrenme Alanı: Geometri ve Ölçme Alt Öğrenme Alanı: Üçgen ve Dörtgenler Süre: $40^{\prime}$

\section{Kazanimlar:}

- M.5.2.2.1. Çokgenleri isimlendirir, oluşturur ve temel elemanlarını tanır.

- M.5.2.2.2. Açlarına ve kenarlarına göre üçgenler oluşturur, oluşturulmuş farklı üçgenleri kenar ve açı özelliklerine göre sınıflandırır.

Beceriler: Problem çözme, iletişim, akıl yürütme, ilişkilendirme, sosyal ve duyuşsal beceriler, psikomotor beceriler

Öğretim Yöntem/Teknikleri: Kâğıt katlama, gösterip-yaptırma, anlatım, buluş yoluyla öğrenme, soru-cevap, gösteri, zekâ oyunu ve örnek olay

Terim/Kavramlar: Çokgen, dik açlı üçgen, dar açılı üçgen, geniş açılı üçgen, ikizkenar üçgen, eşkenar üçgen, çeşitkenar üçgen, paralelkenar, eşkenar dörtgen, yamuk, köşegen

Origaminin Amacı: Açlarına ve kenarlarına göre üçgenler oluşturmak, bu üçgenleri kenar ve açı özelliklerine göre sınıflandırmak.

Malzemeler: Renkli A4 kâğıdı, makas

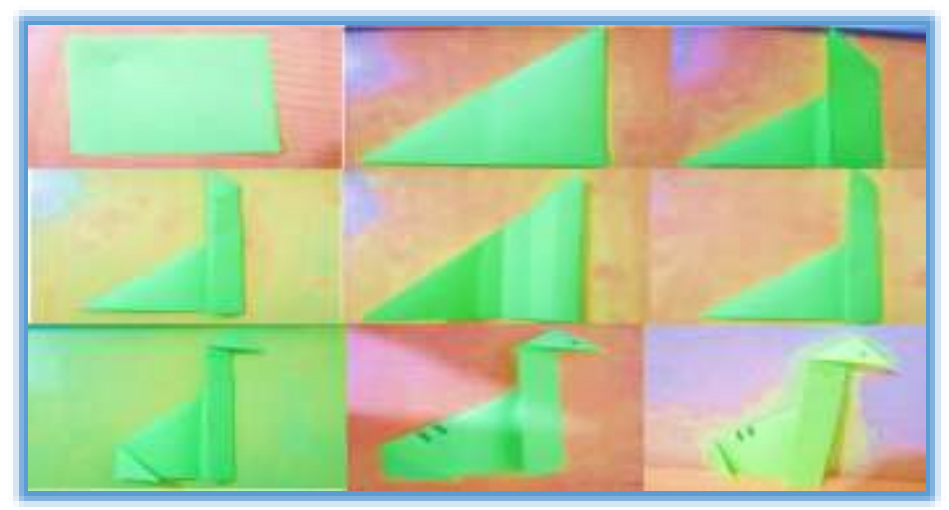

Şekil 1. Dinozor origamisinin yapılış aşamalan

Origaminin Tasarımı: Bir adet renkli A4 kâğıdının bir kenarı $20 \mathrm{~cm}$ olacak şekilde kare şekline getirilir. Köşegen çizgileri belli olacak şekilde katlanır. Daha sonra oluşan üçgen şekil tekrar ikiye katlanır sonra tekrar düzeltilir, kâğıdın ortasına gelecek şekilde tekrar katlanır ve bir yamuk oluşturulur. Yamuk bir kez daha katlanır, sonra tüm şekil açlır. Oluşan çizgiler içe gelecek 
şekilde son kez katlanır, üçgen içeri doğru kıvrılarak dinozorun kafası oluşturulur ve arka kısım kıvrılarak dinozorun kuyruğu oluşturulur. Son olarak dinozorun gözü ve desenleri çizilir.

Origaminin Öğrenme Sürecinde Kullanımı: Öğretmen sınıfa elindeki Origami ile girer ve "sizce bu sadece dinozor mudur?" diye sorar. Öğrenciler merak ederek öğretmenin elindeki dinozor modeline odaklanırlar. Öğretmen; "hadi o zaman hep birlikte yapalım ve görelim der" ve kâğıtları dağıtır, kâğıdı köşegeninden ikiye katladığında, öğrencilere bu üçgenin ne tür bir üçgen olduğunu sorar, öğrencilerden biri, "gönye" yardımı ile ölçerek, "dik üçgen oluştu öğretmenim" der. Öğretmen, öğrencilere dik üçgenin ne olduğunu sorar, öğrenciler: "bir açısı $90^{\circ}$ olan üçgene dik üçgen" dendiğini söyler. Öğretmen öğrencilere bu üçgenin kenarlarının uzunluklarının eşit olup olmadığını sorar; öğrenciler cetvelle kenarları ölçer ve iki kenarının uzunluğunun eşit olduğunu söyler. Öğretmen bu tür üçgenlere ne ad verildiğini sorar, öğrenciler: “ikizkenar üçgen" diye cevap verir. Bu aşamada bir etkinlik hazırlanır. Öğrenciler çantalarından kâğıt, makas, cetvel, renkli kalem ve yapıştırıcılarını çıkarırlar. Açıklama kısmında öğretmen: "Bütün açıları dar açı olan üçgenlere "dar açılı üçgen, bir açısı $90^{\circ}$ olan üçgenlere dik açılı üçgen, bir açısı geniş açılı olan üçgenlere geniş açılı üçgen" dendiğini ifade eder. Derinleştirmede ise izometrik kâğıtlara "dar, dik ve geniş açılı üçgenler" çizdirilir. Bunların çeşitleri sınıflandırılarak bir tabloda gösterilir. Böylece öğrenciler; "çokgen, dik açlı üçgen, dar açllı üçgen, geniş aç1lı üçgen, ikizkenar üçgen, eşkenar üçgen, çeşitkenar üçgen, paralelkenar, eşkenar dörtgen, yamuk, köşegen vb." kavram/terimlerini kavramış olurlar. İstenilen kazanıma ulaşıldığını anlamak için aşağıdaki zekâ oyunu oynatılarak değerlendirme yapılır. Oyun için kâğıt, kalem, açı̈lçer, cetvel, 1'den 6'ya kadar numaralandırılmış sayı küpü ve farklı renkli iki kâğıt parçası gereklidir. Öğretmen aşağıdaki yönergeleri vererek oyunu başlatır:

- KÖ: Kendinize ait farklı renkli kâğıt parçalarını başlangıç noktasına yerleştiriniz.

- KÖ: Strayla sayı küpünü atarak üst yüze gelen sayı kadar ilerleyiniz ve kutuda yazan uygulayıniz.

- KÖ: Üçgen çiz yazan bir kutuya geldiyseniz kendi kâğıdınıza istenilen özellikteki üçgeni çiziniz. Ĕ̆er doğru çizimi yapmazsanı sıra diğer oyuncuya geçer.

- KÖ: Bir tur bekle kutusuna geldiyseniz stra diğer oyuncuya geçer.

- KÖ: Kâ̆ğdınızda eşkenar, ikizkenar ve çeşitkenar üçgenin hepsinden en az birer tane çizdikten sonra bitiş noktasına ulaşmaya çalışını. 
Bitiş noktasına ulaşan ilk öğrenci oyunu kazanır. Tüm sınıfın katılabileceği bu oyunla uygulama bitirilir.

\begin{tabular}{|c|c|c|c|c|}
\hline $\begin{array}{l}\text { Diger oyuncuda } \\
\text { olan Oogenler } \\
\text { den birini clz }\end{array}$ & $\begin{array}{c}1 \text { cesitkenar } \\
\text { dopen giz } \\
\rightarrow\end{array}$ & $\underset{\rightarrow}{1 \text { fur bekle }}$ & $\begin{array}{l}1 \text { ikizkenar } \\
\text { Dopgen ciz } \\
\rightarrow\end{array}$ & $\begin{array}{c}\text { Cizdigin } 1 \\
\text { ohenar Dogen } \\
\text { sil }\end{array}$ \\
\hline $\begin{array}{l}1 \text { egkenar } \\
\text { uggon ciz }\end{array}$ & & $\begin{array}{c}\text { 1. adim ger } \\
\text { don }\end{array}$ & & $\begin{array}{l}1 \text { ģeşitkenar } \\
\text { oppon ciz }\end{array}$ \\
\hline $\begin{array}{c}5 \text { adim geri } \\
\text { dón }\end{array}$ & t tur beide & airis & 1 tur bokle & $\begin{array}{c}2 \text { adim geni } \\
\text { don } \\
\downarrow\end{array}$ \\
\hline $\begin{array}{l}1 \text { Wizkenar } \\
\text { dogon giz } \\
\uparrow\end{array}$ & & $\begin{array}{l}\text { 1. adim gen } \\
\text { dōn }\end{array}$ & & $\begin{array}{l}1 \text { ikizikenar } \\
\text { uppgen ciz }\end{array}$ \\
\hline 3 adim ileri & $\begin{array}{c}1 \text { gesitikenar } \\
\text { üpgen ciz } \\
\leftarrow\end{array}$ & $\begin{array}{c}1 \text { tur bekle: } \\
4-\end{array}$ & $\begin{array}{l}1 \text { eskenar } \\
\text { ocgen giz } \\
4-\end{array}$ & $\underset{4-}{\text { BASILANGIC }}$ \\
\hline
\end{tabular}

Şekil 2. Zekâ oyunu etkinliği

Origaminin Avantajlarn: Görsellik taşıdığı ve öğrencilerin kendileri yaptığı bir model olduğu için kalıc öğrenmeler gerçekleşir.

Origaminin Dezavantajları: Bazı öğrenciler model ile kavramı ilişkilendiremediklerinde zorluk çekebilirler.

Origaminin Maliyeti: 3 TL

\section{Kitap Ayracı Modeli}

Sinıf düzeyi: 5. sinıf

Öğrenme Alanı: Geometri ve Ölçme

Alt Öğrenme Alanı: Üçgen ve Dörtgenler

Süre: $40^{\prime}$

Kazanımlar: M.5.2.4. Üçgen ve dörtgenin iç açılarının ölçüleri toplamını belirler ve verilmeyen açıyı bulur.

Beceriler: Problem çözme, iletişim, akıl yürütme, ilişkilendirme, sosyal ve duyuşsal beceriler, psikomotor beceriler

Öğretim Yöntem/Teknikleri: Kâğıt katlama, gösterip-yaptırma, anlatım, buluş yoluyla öğrenme, soru-cevap, gösteri ve örnek olay

Öğretim Programında Ele Alınan Terim/Kavramlar: "Çokgen, dik açılı üçgen, dar açlı üçgen, geniş açılı üçgen, ikizkenar üçgen, eşkenar üçgen, çeşitkenar üçgen, paralelkenar, eşkenar dörtgen, yamuk, köşegen" 
Disiplinler Arası İlişkilendirme: Öğrenciler, 7. sınıf "Teknoloji ve Tasarım” dersinde verilen proje ödevinde öğrenciler bireysel-grup-işbirlikli yaklaşımla kitap ayracı origamisini hazırlayarak bir kitapçı yapıp köy okullarına dağıtılabilir. Böylece öğrencilerin kitap okuma alışkınlarına olumlu bir etki ve katkı yapılmış olunur.

Origaminin Amacı: Üçgen ve dörtgenin iç açları toplamını belirlemek ve verilmeyen açıyı bulmak.

Malzemeler: Renkli A4 kâğıdı, renkli kalem

Origaminin Tasarımı: Bir A4 kâğıdı kenarları $10 \mathrm{~cm}$ olan bir kare haline getirilir. Kare haline getirilmiş kâğıt köşegeni üzerinden katlanarak üçgen oluşturulur. Üçgen şeklin alttaki iki köşesi üst üste gelecek şekilde katlanır ve aç1lır. Üçgenin ortasında bir bir çizgi oluşturur. Üçgenin üst köşesi çizginin üzerine gelecek şekilde katlanır. Diğer iki köşesi de çizginin üzerine gelecek şekide katlanır. En son katlanan iki köşe altta oluşan araya geçirilir. Oluşan şekil istenilen biçimde süsleyerek kitap ayracı model oluşturulmuş olur.

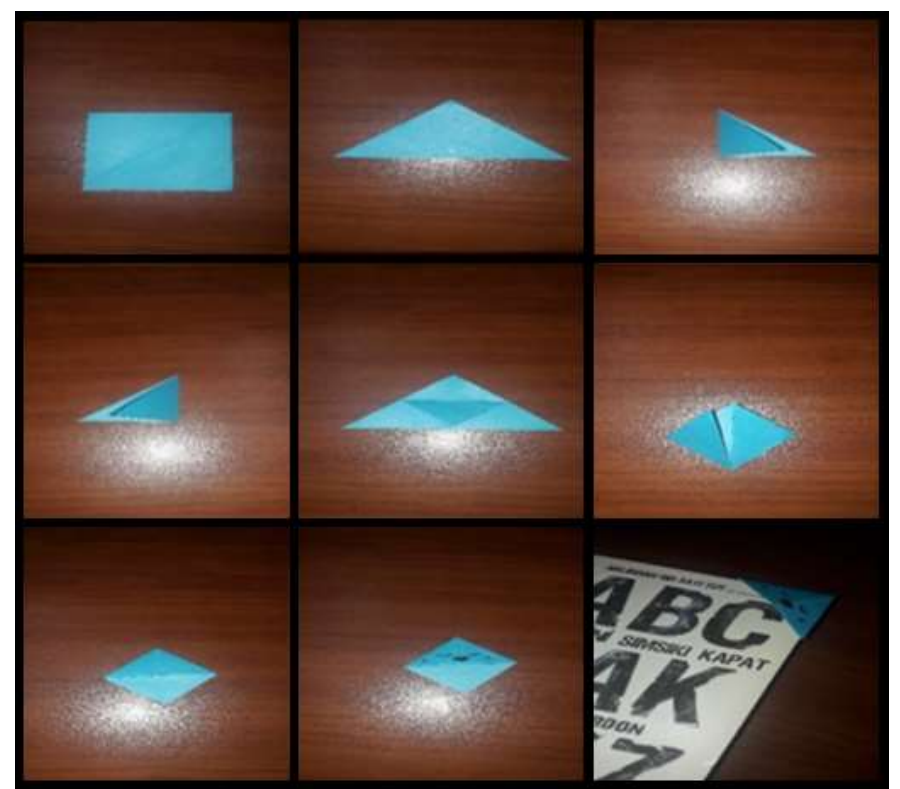

Şekil 3. Kitap ayracı origamisinin yapılış aşamalan

Origaminin Öğrenme Sürecinde Kullanımı: Öncelikle giriş aşamasında öğrencilerin hazırbulunuşluğuna uygun olarak ilgili origamide hangi şekiller 
olduğu sorulur. Öğrencilerden "üçgen ve kare" cevabı alınır. Daha sonra akıllı tahtadan çeşitli fotoğraflar gösterilerek öğrencilere merak uyandırılır. Öğrenciler fotoğrafları inceledikten sonra bu fotoğraftaki görselleri daha önce görüp görmedikleri ve fotoğraftaki nesnelerin hangi geometrik şekillere benzediği sorulur. Öğrencilerden: “üçgen, paralelkenar, dikörtgen, eşkenar dörtgen, yamuk, kare" cevabını alır. Daha sonra "Üçgen ve dörtgenin iç açılarının ölçüleri toplamım belirler ve verilmeyen açıyı bulur." kazanımının öğretimine geçilerek öğrencilerin konuyu keşfetmeleri sağlanır. Öğretmen öğrencilerine bugünkü derste bu şekilleri daha iyi öğrenmek için origami yapacaklarını söyleyerek, onlara kare şeklinde kâğıtlar dağıtır. Origami modelinin yapılış aşamaları gösteriip-yaptırma yöntemi ile yaptırılır. Öğretmen modeli açarak üçgen haline getirip üçgenin iç açıları toplamının $180^{\circ}$ ve dikdörtgenin iç açları toplamının $360^{\circ}$ derece olduğunu gösterir. Öğrencilerin origami modellerini bozmamaları için onlara üçgen kâğıtlar dağıtır. Öğretmen üçgenin iç açılarını renkli kalemlerle boyamalarını ister. " $A B C$ üçgeninin köşelerini $[B C]$ üzerinde bir noktada kesişecek" ş̧ekilde yukardaki gibi katlatır. Oluşan şeklin nasıl bir açı oluştuğu sorulur. Öğrenciler ön öğrenmelerine uygun olarak "doğru açı" cevabını verir. Öğretmen: "doğru açının ölçüsü $180^{\circ}$ derece olması nedeniyle ABC üçgeninin iç açılarının ölçüleri toplamı da $180^{\circ}$ " olduğunu söyler. Benzer şekilde dikdörtgen için de gösterilir. Açıklama aşamasında dağıtılan üçgenlerin boyanan iç açıları "açı̈llçer" yardımıyla ölçülmesini ve ölçüleri bulunan ölçülerle aynı olan üç açıyı şekildeki gibi yan yana çizmelerini ister.

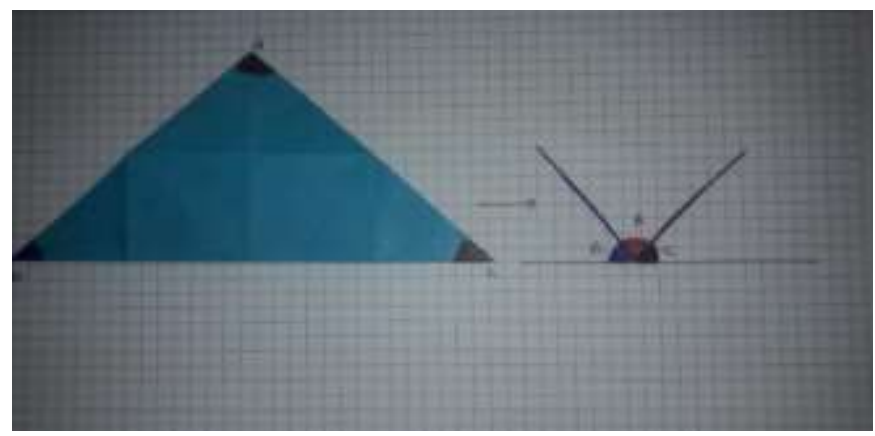

Şekil 4. Açı etkinliği

Öğretmen bu şekilde üçgenin iç açılarının toplamıla ilgili kazanımı bir daha açılamış olur. Daha sonra öğretmen tahtaya " $70^{\circ}, 25^{\circ}, 55^{\circ \prime}$ açı ölçüleri 
yazılarak ölçülerin bir üçgene ait olup olmadığı sorar ve defterlerine yapmaları ister. Defterlerinde buldukları cevaplardan sonra öğretmen: "üçgen olması için iç açıları toplamı $180^{\circ}$ olmalıdır" der ve " $70^{\circ}+25^{\circ}+55^{\circ}=130^{\circ}$ olduğundan bu açlar bir üçgene ait değ il, " $85^{\circ}+45^{\circ}+50^{\circ}=180^{\circ}$ olduğundan bu açılar bir üçgene aittir" der. Öğretmen bu sefer tahtaya " $100^{\circ}, 113^{\circ}, 74^{\circ}, 36^{\circ}$ " açı ölçülerini yazarak ölçülerin bir dörtgene ait olup olmadığını sorar ve " $135^{\circ}, 42^{\circ}, 84^{\circ}, 99^{\circ}$ " açılarını defterlerine yazmaların ister. Defterlerinde buldukları sonuçlardan sonra öğretmen "dörtgen olması için iç açıları toplam $360^{\circ}$ olmalıdır" der ve " $100^{\circ}+113^{\circ}+74^{\circ}+36^{\circ}=323^{\circ}$ " olduğundan bu açılar bir dörtgene ait değil, " $135^{\circ}+$ $42^{\circ}+84^{\circ}+99^{\circ}=360^{\circ}$ olduğundan bu açlar bir dörtgene aittir" der. Derinleştirme aşamasında öğrencilerden iki açısının ölçüsü " $50^{\circ}$ ve $70^{\circ}$ ” olan değişik büyüklükte iki üçgen çizdirilip bu üçgenlerin üçüncü açısının ölçüsünü bulmaları istenir. İki üçgeninde üçüncü açısı " $60^{\circ}$ ” olduğunu bulan öğrencilerin cevabına öğretmen: "iki iç açısı aynı olan farklı büyüklükte iki üçgenin üçüncü açılarının aynı olduğunu farklı büyüklükte olsalar da önemli olan iç açıları" olduğunu söyler. Dörtgenler için de benzer alıştırmalar yapılır. Daha sonra öğretmen tahtaya iç açıları verilen dik, dar ve geniş açılı birer üçgen çizer, öğrencilerden iç açıları toplamın bulmaları ister. Üçgen çeşitlerinin farklı olması üçgenin üç açıları toplamını değiştirip değiştirmediği tartışılır. Bütün üçgen çeşitlerinin iç açıları toplamını $180^{\circ}$ bulan öğrencilere, değiştirmediği sonucuna vardırılır. Ardından öğretmen; "Sürpriz civcivler" etkinliğini yaptırır. Bu etkinlik öğretmenin daha önce kitap ayracı modelini kullanarak oluşturduğu civcivlere "üçgende verilmeyen açıyı bulma" kazanımına ilişkin yazdığı soruları sırayla çözmeleri istenir. Doğru cevabı bulan öğrenci civcivlerin içindeki sürprizleri kazanır. Değerlendirme aşamasında verilen bazı üçgen ve dörtgenin "verilmeyen açısını bulmaya" yönelik örnekler çözdürülür. Son aşamada öğretmen; "dörtgen şeklindeki kâ̆ğıdın kısa kenarları üst üste gelecek biç̧imde katlanmış hâli verildiğini düşünün. Kâğıt, noktalı çizgiler boyunca kesiliyor ve kesilen küçük parça açllyor. Açılan bu parçanın şeklini çiziniz ve iç açılarının ölçüleri toplamın belirleyiniz" diyerek bir etkinlik daha yaptırır. Ardından sınıfta dikdörtgen şeklinde bir kâğıdı şekildeki ölçülerde keserek sınıfta görsel olarak gösterilir. Kesilince oluşan şeklin bir yamuk olduğunu bütün sınıf görür ve öğrencilerin tamamı: "yamuğun iç açları toplamı $360^{\circ}$ " diyerek uygulama sonlandırılır. 
Origaminin Avantajlarn: Öğrencinin psikomotor becerileri geliştirerek aynı zamanda yaparak-yaşayarak öğrenmesini sağlanmış, iletişim becerileri artmış, konu somut bir modelle anlatıldığı için öğrencilerin kavramı öğrenmeleri sağlanmış olur.

Origaminin Dezavantajları: Öğrencinin devinişsel becerileri yeterince gelişmemişse origamiyi hazırlarken zorlanabilir dolayısıyla da derse karşı motivasyonu düşebilir.

Origaminin Maliyeti: 3 TL

\section{Bulgular}

Aşağıda verilerin analizi sonucu elde edilen bulgular; öğretmen adaylarının karşılaştıkları zorluklar, öğrencilere ve öğretmen adaylarına sağladığı katkılar şeklinde ele alınmış, her bir temaya ait kodlar tablolar halinde sunulmuş ve öğretmen adaylarının cevaplarından alıntılar yapılmıştır.

\section{Öğretmen adaylarnın klasik origami tabanl öğretim uygulamalarnda kar- şılaştıkları zorluklara ilişkin bulgular}

Alt problemlere göre elde edilen bulgular aşağıda sırasıyla tablolar halinde sunulmuştur.

Tablo 1. Öğretmen adaylarının karşılaştıkları zorluklar

\begin{tabular}{|c|c|c|}
\hline Tema & Kodlar & f \\
\hline \multirow{7}{*}{$\begin{array}{l}\text { Öğretmen } \\
\text { adayı }\end{array}$} & Öğrencilere origami modelini yaptırmada zorlanma & 11 \\
\hline & Öğrencilerle origamiyi yaptıktan sonra uygulamaya geçmede zorluk yaşama & 10 \\
\hline & Öğrencilere origami yaptırırken yönerge vermede problem yaşama & 8 \\
\hline & Öğrencilerin sınıf kontrolünü sağlamada problemle karşılaşma & 6 \\
\hline & Geometri kavramlarını öğretirken zorluk yaşama & 1 \\
\hline & Öğrenme güçlüğü çeken çocuklara geometri öğretmede problem yaşama & 1 \\
\hline & Geometri bilgisinin yetersiz oluşundan kaynaklı problem yaşama & 1 \\
\hline \multirow[t]{5}{*}{ Öğrenci } & $\begin{array}{l}\text { Öğrencilerin hazırbulunuşluklarının çok eksik olması nedeniyle öğretimde prob- } \\
\text { lem yaşama }\end{array}$ & 18 \\
\hline & Öğrencilerin uygulama yapmak istememeleri & 2 \\
\hline & Bazı öğrencilerin çok çabuk sıkılması & 1 \\
\hline & Bazı öğrencilerin uygulamada ele alınan soruları yapamayacaklarını düşünmesi & 1 \\
\hline & Origami modeli yaptırmanın zaman alıcı olması & 9 \\
\hline \multirow[t]{2}{*}{ Zaman } & $\begin{array}{l}\text { Öğrencilerin hazırbulunuşluluk düzeylerinin düşük olması nedeniyle uygu- } \\
\text { lamada çok zaman kaybedilmesi }\end{array}$ & 8 \\
\hline & Zamanı etkin kullanamama & 6 \\
\hline
\end{tabular}


Tablo 1 incelendiğinde; öğretmen adaylarının karşılaştığı zorlukların üç temaya aydıldığı görülmektedir. “Öğretmen adayı” teması incelendiğinde 11 katılımcı öğrencilere origami modelini yaptırmada zorlandığını, 10 katılımcı origamiyi yaptıktan sonra uygulamaya geçmede zorluk yaşadığını, 8 katılımc da öğrencilere origami yaptırırken yönerge vermede problem yaşadığını belirtmiştir. "Öğrenci" teması incelendiğinde, 18 katılımcı öğrencilerin hazırbulunuşluklarının çok eksik olması nedeniyle öğretimde problem yaşandığını belirtmiştir. "Zaman" teması incelendiğinde; 9 katılımcı origami modeli yaptırmanın zaman alıcı olduğunu, 8 katılımcı öğrencilerin hazırbulunuşluk düzeylerinin düşük olması nedeniyle uygulamada çok zaman kaybedildiğini ve 6 katılımc ise, zamanı etkin kullanamadığını belirtmiştir.

Katılımcların Tablo 1'deki "Öğretmen Adayı-Öğrenci-Zaman" temalarına ilişkin cevaplarından bazıları şöyledir:

- Öğrencilere origamiyi yaptırırken çok uğraştım, çok konuştukları için yönergeleri anlayamadılar, çok zormuş çocuklara böyle bir etkinlik yaptırmak, onu anladım... (Öğretmen adayı-K22)"

- Susmuyorlar bir türlü... Origamiyi gösterip yaptırırken kan ter içinde kaldım... (Öğrenci-K25)"

- "Sinıf savaş alanı gibiydi... Ne yapacağımı bilmedim. Allahtan hocamız geldi duruma el koydu da modeli yaptırabildim.... (Öğrenci-K38)"

- Öğrenciye üçgenin açlarım dinozor origamisinin üzerinde gösterdiğim halde, 15 dakika sonra benzer şekilde bir soru sorulduğunda soruyu bilememesi, meğer üçgen ile ilgili pek çok eksiği varmış. Hazırbulunuşluk olmadan olmuyor hiçbir şey... (Öğrenci-K12)"

- Origami yapmak umduğumdan daha fazla zamanım aldı. Öğrencilere yönergeyi vermek, origamiyi eş zamanli yapmak çok zormuş... (Zaman-K26)"

- Çocuğa origamiyi yaptırırken ya da soruyu çözmesini isterken çokbekledim, zamanı etkin kullanamadığımı fark ettim... (Zaman-K27)"

\section{Klasik origami tabanlı öğretim uygulamalarının öğrencilere să̆ladı̆̆ı katkılara ilişkin bulgular}

Alt problemlere göre elde edilen bulgular aşağıda tablolar halinde sunulmuştur. 
Tablo 2. Öğrencilere să̆ladı̆̆ı katkılar

\begin{tabular}{|c|c|c|}
\hline Tema & Kodlar & $\mathrm{f}$ \\
\hline \multirow[t]{13}{*}{ Matematik Öğretim Programı } & Kazanımları öğrenme & 18 \\
\hline & Geometriyi daha iyi öğrenme & 16 \\
\hline & Kâğıt katlama yöntemini kullanarak origami yapmayı öğrenme & 14 \\
\hline & Uzamsal ve 2-3 boyutlu düşünmeyi sağlama & 10 \\
\hline & Dersin içeriğini öğrenme & 4 \\
\hline & Problem çözme becerisi geliştirme & 7 \\
\hline & Farklı yöntem/teknikleri görme & 7 \\
\hline & Somut model/materyallerle matematik becerisi geliştirme & 6 \\
\hline & Matematiğe değer vermeyi kazanma & 1 \\
\hline & Matematiksel dil kullanmayı geliştirme & 1 \\
\hline & Matematiksel düşünme becerisini geliştirme & 1 \\
\hline & Akıl yürütme becerilerini geliştirme & 1 \\
\hline & Kök değerlerin önemini anlama & 1 \\
\hline \multirow[t]{9}{*}{ Sosyal ve Duyuşsal Gelişim Alanı } & Eğlenerek öğrenmeyi gerçekleştirme & 16 \\
\hline & İlgi ve dikkat çekme & 15 \\
\hline & Merak etme & 7 \\
\hline & Matematikle oynadığını düşünme & 5 \\
\hline & Matematiği sevme & 5 \\
\hline & Ön yargiları yıkma & 1 \\
\hline & Sorumluluk alma & 1 \\
\hline & Öz güven geliştirme & 1 \\
\hline & Derse odaklanma & 1 \\
\hline Devinişsel Gelişim Alanı & Kâğıt katlama, kesme, boyama ve yapıştırma yapma & 24 \\
\hline
\end{tabular}

Tablo 2' de öğrencilere katkıları 3 tema altında incelenmiştir. "Matematik öğretim programı" teması incelendiğinde; 18 katılımc öğretim programındaki kazanımları öğrendiğini, 16 katılımcı geometriyi daha iyi öğrendiğini, 14 katılımcı ise, kağıt katlama yöntemini kullanmayı öğrediğini belirtmiştir. "Sosyal ve duyuşsal gelişim alanı" teması incelendiğinde; 16 katılımcının eğlenerek öğrenmeyi gerçekleştirme, 15 katılımcının ilgi ve dikkat çekme, 7 katılımcının merak etme cevaplarını verdikleri görülmektedir. “Devinişsel gelişim alanı" temasında ise, 24 katılımcı öğrencilerin kağıt katlama, kesme, boyama ve yapıştırma gibi psikomotor becerilerine katkı yaptı̆̆ını ifade ettiği görülmektedir.

Katılımcıların Tablo 2'deki “Matematik Öğretim Programı-Sosyal ve Duyuşsal Gelişim Alanı-Devinişsel Gelişim Alanı" temalarına ilişkin cevaplarından bazıları şöyledir:

- "Yaptırdığım Origami ile zaten hayvanlarn seven çocuğa geometi kazanımlarmı ögrrettim, ben de öğrendim... (Matematik Öğretim Programı-K20)" 
- Öğrenciler origami yaparken dersin oyun gibi olduğunu ve matematiğin daha eğlenceli olduğunu düşündüklerini söylediler... (Sosyal ve Duyuşsal Gelişim Alant-K29)"

- Yaptırdığım dinozor Origami modelinde kâğıtlar katlarken çocuklar birlikte çalıştılar. Origami ile hiç makas tutmayan çocuğa diğer arkadaşı makasla kesmeyi gösterdi... (Devinişsel Gelişim Alanı-K17)"

Klasik origami tabanl öğretim uygulamalarının öğretmen adaylarına să̆ladı̆̆ı katkılara ilişkin bulgular

Alt problemlere göre elde edilen bulgular aşağıda sırasıyla tablolar halinde sunulmuştur.

Tablo 3. Öğretmen adaylarına sağladiğı katkılar

\begin{tabular}{|c|c|c|}
\hline Tema & Kodlar & f \\
\hline \multirow{15}{*}{ Mesleki Gelişim } & Kâğıt katlama yöntemini kullanma & 28 \\
\hline & Origami yapmayı ve yaptırmayı öğrenme & 26 \\
\hline & Dersi ilgi çekici hale getirmeyi öğrenme & 22 \\
\hline & Derse hazırlanma konusunda deneyim kazanma & 20 \\
\hline & Mesleki deneyim kazanma & 20 \\
\hline & Ders planı hazırlamayı öğrenme & 18 \\
\hline & Matematiği günlük hayatla ilişkilendirme & 16 \\
\hline & Çeşitli yöntem/teknikler kullanmayı öğrenme & 7 \\
\hline & Öğrenciyi tanıma & 6 \\
\hline & Tecrübe sâhibi olma & 7 \\
\hline & Öğretmenlik provası yapma & 5 \\
\hline & İşbirlikli yaklaşımı kullanma & 4 \\
\hline & Buluş yöntemini uygulama & 1 \\
\hline & Keşfederek-yaparak-yaşayarak öğrenme yöntemini kullanma & 1 \\
\hline & Öğretmenliğin değerini daha iyi anlama & 1 \\
\hline \multirow{5}{*}{ Kişisel Gelişim } & Sabretmeyi ve hoşgörülü olmayı öğrenme & 26 \\
\hline & Sınıf karşısında heyecanını kontrol etme & 11 \\
\hline & Eksiklerini görme & 2 \\
\hline & Sınıf kontrolünü sağlamayı öğrenme & 1 \\
\hline & Dersi geçme & 1 \\
\hline
\end{tabular}

Tablo 3 incelendiğinde öğretmen adaylarına katkıları 2 tema altında toplanmıştır. "Mesleki gelişim" teması incelendiğinde; 28 katılımcı kâğıt katlama yöntemini kullandığını, 26 katılımcı origami yapma ve yaptırmayı öğrendiğini, 22 katılımcının ise, dersi ilgi çekici hale getirmeyi öğrendiğini belirtmiş- 
tir. "Kişisel gelişim" teması incelendiğinde; 26 katılımcı sabretmeyi ve hoşgörülü olmayı öğrendiğini, 11 katılımcı da sınıf karşısında heyacanını kontrol etmeyi öğrendiğini belirtmiştir.

Katılımcların Tablo 3'deki “Mesleki Gelişim-Kişisel Gelişim” temalarına ilişkin cevaplarından bazıları şöyledir:

- "Matematik öğretiminin nasıl daha ilgi çekici hale gelebileceğini öğrenmiş oldum, Kâ̆̆ıt katlama yönteminin bir mucize olduğunu gördüm... (Mesleki Gelişim-K4)"

- "İyi ki origami yapmayı biliyorum, ileride öğrencilerim çok şansh olacak. Birçok konuyu origami ile 10 dakikada öğretebilirim... Çok hoşuma gitti, tabi çocuklarm da... (Mesleki Gelişim-K33)"

- "Ben çok sabırsız, tez canl biriydim, ancak origami uygulamalar bana sabretmeyi ögretti. Öğretmen olunca daha sabırlı olurum sanırım... (Kişisel GelişimK9)"

- “Bir süre sonra simffi kontrol etmeyi, onları susturmayı öğrendim... (Kişisel Gelişim-K63)"

\section{Tartışma ve Sonuç}

Bu çalışmada, araştırmacının rehberliğinde öğretmen adaylarının “Üçgen ve Dörtgenler" alt öğrenme alanının bazı kazanımlarının öğretimine uygun tasarladıkları etkinlikler öğrencilere uygulanmıştır. Öğretmen adaylarının origami tabanlı etkinliklerin öğrencilere uygulanması sürecinde karşılaştıkları zorlukları ve sağladığı katkıları ortaya koymak amacıyla hazırlanan çalışmada, bulgulara dayalı olarak yapılan tartışma sonucunda aşağıdaki sonuçlara ulaşılmıştır:

Uygulamalarda karşılaşılan problemlere katılımcilar açısından bakıld1ğında; "öğrencilere origami modelini yaptırmada, modeli yaptıtırken yönerge vermede, modeli yaptıktan sonra uygulamaya geçmede, sinf kontrolünü sağlamada, geometri ögrretmede ve geometri bilgisinin yetersiz oluşundan kaynakl problem yaşama" gibi zorluklar elde edilen sonuçlar arasındadır. Origami tabanlı öğretim uygulamaları ile gelecekte bu görevi yerine getirecek olan öğretmen adaylarının karşılaştıkları zorlukların üstesinden gelmek için bu tür uygulamalara alıştırılması yerinde olacaktır.

Uygulamalarda katılımcların karşılaştıkları zorluklardan öğrenci boyutuna bakıldığında; "öğrencilerin hazırbulunuşluklarının çok eksik olması nedeniyle 
öğretimde zorlanma, uygulama yapmak istememeleri, bazı öğrencilerin çok çabuk slkılması ve uygulamada ele alınan sorular yapamayacakların düşünmesi" gibi sorunlar ortaya çıkmıştır. Bu bağlamda, öğrencilerin matematik ve geometri konularında yaşadıkları zorlukların giderilmesi amacıyla zaman zaman öğrencilere origami ile uygulama yaptırılarak konuyu daha iyi kavramaları sağlanabilir. Öğrencilerin okul yıllarında matematikte yaşadıkları bazı problemler, öğrenmekten korktukları ya da istemedikleri konu-kavramlar, klasik origami tabanlı etkinlikler uygulanarak ortadan kaldırılabilir. Öğrencilere 15-25 dakikada çiçek, yıldız, gül, çiçek, şapka, kedi, kurbağa, tilki, dinozor, köpek, dönme dolap, rüzgârgülü, tuzluk, kitap ayracı, dondurma, gemi, uçak gibi klasik origami modellerini yaptırıp, matematiği sevmelerini engelleyen durumları ortadan kaldırmış, matematik öğrenmenin keyfini onlara yaşatmış oluruz (Hacısalihoğlu Karadeniz, 2017).

Uygulamalarda katılımcıların yaşadıkları zorluklar zaman açısından incelendiğinde ise; "zaman etkin kullanamam ve öğrencilerin hazırbulunuşluluk düzeylerinin düşük olması nedeniyle uygulamada çok zaman kaybedilmesi" bulgularına ulaşılmıştır. Klasik origami modeli hazırlamak parçalı origami modeli hazırlamaya göre daha kısa süren bir uygulamadır (Hacısalihoğlu Karadeniz, 2017). Ancak öğretmen adaylarının, ortaokulda bir sınıf ortamında bu tür uygulamaları yaptırmaya alışı olmaması nedeniyle zaman konusunda problem yaşandığını düşündürmektedir. Bu durum daha ikinci sınıfta öğrenim gören öğretmen adayı için olağan bir durumdur denilebilir.

Uygulamaların öğrencilere katkıları program açısından ele alındığında; "programdaki kazanımları ve geometriyi öğrenme, dersin içeriğini öğrenme, kâğıt katlama yöntemini kullanarak origami yapmayı öğrenme, farklı yöntem/teknikleri görme, somut model ve araç-gereç kullanma, matematik dilini geliştirme, matematiğe değer verme, uzamsal ve 2-3 boyutlu düşünme, matematiksel düşünme-problem çözme-akıl yürütme becerisini geliştirme" olarak karşımıza çımıştır. Bu sonuçlara paralel olarak katılımcıların öğrencilerin akademik becerilerini geliştirmeyi daha iyi algıladıkları söylenebilir. Son dönemlerde kağıt katlama yöntemiyle matematik öğretmeye yer verilmektedir (Yuzawa ve Bart, 2002; Mastin, 2007; Çakmak, 2009; Golan ve Jackson, 2010; Hacısalihoğlu Karadeniz, 2017, 2018). Ayrıca bu yöntemin matematik öğrenmede bilişsel, davranışsal ve fiziksel katılımı artırarak öğrenmeyi kolaylaştırdığı söylenebilir (Brady, 2008; MEB, 2011). Bu sonuçlar mevcut çalışmanın sonuçlarıyla benzerlik göstermektedir. Öğrenci origami yapmaya çalışırken; nokta, doğru, açı, deltoid, 
açırtay, simetri ekseni, kare, üçgen vb. geometrik kavramları model üzerinde oluşturmak zorundadır. Bu kavramlar Öklid geometrisini oluşturur, dolayısıyla origamiyle uğraşan öğrenci kâğıt katlarken Öklid geometrisini de öğrenebilir. Öğrenci, origami uygulamalarıyla alan ile hacim arasında bir ilişki kurabilir, kenar uzunluklarını ve oluşan alanları hesaplarken geometrik şekilleri cebirsel olarak ifade edebilir, böylece geometri ile cebir arasında da bir ilişki kurmuş olur (MEB, 2011). Öğrenci modelleri katladıkça estetiğin önemini kavrar ve sabırlı olmayı öğrenmsinin yanı sıra, kâğıdı kuşa, uçağa, gemiye dönüştürürken oluşturduğu modelin geometrik özelliklerini algılar, şekilleri dönüştürürken farkında olmadan "dönüşüm" kavramını da algılamış olur, aynı zamanda origami ile uğraşan bir öğrenci "iki ve üç boyutlu düşünebilme" becerisini de geliştirir (MEB, 2011). Buna ek olarak, güncellenen öğretim programında; iç açıların ölçüleri toplamı bulunurken kâğıt katlama veya uygun modellerle yapılacak etkinliklere yer verilmesine dikkat çekilmektedir (MEB, 2017).

Uygulamaların öğrencilere katkılarına program açısından bakıldığında; origaminin matematik dilini geliştirmeye katkısının olduğu elde edilen sonuçlar arasındadır. NCTM (1991)'nin matematik öğretmenlerinin mesleki gelişimi standartlarında; öğretmenlerin öğrencilerin matematiksel fikirlerini yazılı/sözlü olarak açılamalarını istemeleri, matematik dilini öğrencilerin fikirleri ile ne zaman ve nasıl ilişkilendireceklerini bilmeleri gerektiği vurgulanmaktadır. Dolayısıyla öğretmenler tarafından, öğrencilerin matematiksel iletişim ve dil becerilerinin gelişimini destekleyen öğrenme ortamlarının tasarlanması gerekmektedir (Kotsopoulos, 2007). Kabael ve Ata Baran (2016) çalışmalarında, öğretmenlerin matematik dilinin etkin kullanımını önemsediklerini ancak öğrencilerinin matematiksel iletişim becerilerini geliştirme hakkında farkındalıklarının olmadığı, üstelik programdaki matematiksel iletişim becerileri kazanımlarından haberdar olmadıkları sonuçlarına ulaşmışlardır. Eldeki çalışmada ise, en azından bir öğretmen adayının origami tabanlı öğretim uygulamalarının matematiksel dil kullanmayı geliştirdiğini hizmet öncesinde düşünmesi kayda değer bir sonuçtur. Bir başka açıdan bakılacak olursa, öğretmen öğrenciye model ile ilgili yönergeyi verir, öğrenci öğretmeni dikkatlice dinler, doğru dinlediğinde de doğru anlama becerisi kazanır. Ĕ̆er öğrenci modeli arkadaşlarına yaptırıyorsa, kendi dilini iyi kullanarak sözlü ifade etme, anlatım ve dil becerisini kazanmış olur (MEB, 2011). Sonuç olarak, 
origami tabanlı uygulamalar ile işlenen derslerle öğrencilerin matematik terminolojisini doğru bir şekilde kullanmaları sağlanarak gelecekte iyi birer matematik okuryazarı olmaları beklenebilir.

Uygulamalarının öğrencilere sağladığı katkılara sosyal-duygusal gelişim alanı açısından bakıldığında; "eğlenerek öğrenme, ilgi ve dikkat çekme, merak etme, matematiği sevme" kodları elde edilmiştir. Öğrenci origamiyi oyun olarak algıladığı için etkili bir eğitsel araçtır denilebilir (MEB, 2011). Öğrencilere; matematiği uğraşmaya değer ve önemli görmelerine, matematiğe ilgi duymalarına ve matematiğe gereken değeri vermelerine, özen ve sabırla çalışmalarını sağlayacak uygulamalar yaptırılması önem arz etmektedir (MEB, 2013). Origami ile yapılan uygulamalar; grup çalışması yapılmadığı durumlarda bile paylaşma ve yardımlaşma bilincini oluşturur, origami belli kurallar çerçevesinde tamamlandığı için kurallara saygı duymayı, modelleri katladıkça estetiğin önemini kavramayı ve sabırlı olmayı öğrenir (MEB, 2011). Öğrencininnn seçtiği kâğıdın rengine, boyutuna kendi karar vererek, kendi şeklini, yaratıc1lığını kullanarak hayal ettiği modeli oluşturur böyleikle öz güveni gelişir, ortaya bir eser koyacağı için de kendisini çevresindekilere kabul ettirebilme firsatı yakalar (MEB, 2011), böylelikle matematik dersine olan ön yargıların oluşması engellenerek matematiğe karşı olumlu tutum beslemeleri sağlanabilir (Boakes, 2008; Çakmak, 2009; Tuğrul ve Kavici, 2002). Origami etkinlikleri, matematiksel kavramları somut ve açık bir şekilde ortaya koyduğundan, matematiğin sevilmemesinde etken olan soyut tarafını ortadan kaldırmaktadır (MEB, 2011). Sonuç olarak, klasik origami uygulamalarının, öğrencinin duyşsal ve davranışsal gelişimine olumlu katkılar sağladığı söylenebilir.

Uygulamaların öğrencilere sağladığı katkılar devinişsel gelişim alanı açısından ele alındığında katılımciların; "öğrencilerin kağıt katlama, kesme, boyama ve yapıştırma gibi psikomotor becerilerine katkı yaptığııı" ifade ettikleri görülmektedir. Programda, sürece dahil edilen somut model, materyal ve milimetrik, noktalı ve izomerik kâğıtları etkin kullanma, kâğıt katlayarak geometrik şekiller, matematiksel ilişkiler, desenler, eşya figürleri oluşturma, öğrencilerin bilişsel-sosyal ve duyuşsal-psikomotor becerilerinin gelişimine katkı sağladığı ifade edilmektedir (MEB, 2009). Origami uygulamalarının öğrencinin psikomotor becerilerinin gelişimine yansımalarına bakıldığında; küçük kas gelişimini sağlıklı tamamlamasını, aynı anda el, göz, el gibi birçok organını bir arada kullanabilmesini sağladığı görülmektedir (MEB, 2011). Kâ̆̆ıt katla- 
manın tüm bireylere en ilginç gelen yönü tek bir kâğıdın bile kesilmeden bütün bir şekle dönüşmesi ve kâğıt katlama ile çeşitli geometrik şekillerden yola çıkarak insan, hayvan, eşya, çiçek gibi pek çok model elde edilebilir olmasıdır (Haga, 2008; Krier, 2007). Katlama işi görsel, sosyal ve duyuşsal, işitsel ve bedensel etkinlikleri içerir (Tuğrul ve Kavici, 2002) dolayısıyla, origami eğitimde bir yöntem olarak kullanılabilir (Arıc1, 2013; Arslan vd., 2013; Boakes, 2009; Chen, 2006; Golan ve Jackson, 2010; Philipp 2007). Öğretim programında; "bir işin yapılması sırasında kullanılan bilinçli zihinsel etkinliğin yönlendirdiği koordineli kas etkinlikleri olarak tanımlanan psikomotor becerileri; bitişik eğik yazı yazma, resim yapma, kâğıt katlama ve kesme, top atma, keman çalma gibi beceriler" olarak tanımlanmıştır (MEB, 2017). Bu bağlamda Gür ve Kobak-Demir (2016) çalışmasında, öğretmen adaylarının matematik laboratuvarında öğrencilerin keşfederek öğrenmelerine imkan tanıyan origami etkinlikleri ile öğrencilerin devinişsel becerilerini geliştirdiğini ifade etmiştir. Bu sonuçlar eldeki çalışmanun sonuçlarıyla paralellik göstermektedir. Benzer şekilde NCTM'nin (2000) belirlediği standartlarda da, öğrencilerin kendi öğrenme süreçlerinde daha aktif olabilmeleri, öğretmenlerin somut nesne, materyal ya da model kullanılmasına bağlı olduğu vurgulanmaktadır. Kısaca yapılan aktiviteler; devinişsel, sosyal ve duygusal becerileri kazandırmanın yanı sıra matematiksel ifade ve sembolleri kullanmayı, model oluşturmayı, akıl yürütmeyı ve soyutlama yapmayı sağlayan uygulamalar olduğundan (Baki, 2008), bilişsel gelişim alanına oldukça fazla katkı sağlar.

Uygulamaların öğretmen adaylarına sağladığı katkılar, "kişisel gelişim ve mesleki gelişim" olarak sınıflandırılmıştır. Katılımcıların mesleki gelişime ilişkin katkıları; "kâğıt katlama yöntemini kullanma, origami yapmayı ve yaptırmayı-dersi ilgi çekici hale getirmeyi öğrenme, derse hazırlanma-mesleki deneyim kazanma, ders planı hazırlamayı-çeşitli yöntem/teknikler kullanmayı öğrenme, matematiğ günlük hayatla ilişkilendirme, öğrenciyi tanıma, tecrübe sâhibi olma, öğretmenlik provası yapma" olarak ortaya çıkmıştır. Katılımcların kişisel gelişime ilişkin katkıları ise; "sabretmeyi ve hoşgörülü olmayı öğrenme, sımıf karşısında heyecanin kontrol etme, eksiklerimi görme, sinıf kontrolünü sağlamayı öğrenme ve dersi geçme" olarak betimlendiği görülmektedir.

"Kâğıt Katlama Yöntemi ile Matematik" ya da "Origami" dersi 2018-2019 eğitim-öğretim yılı da dahil olmak üzere Türkiye'deki bazı üniversitelerde seçmeli bir ders olarak yürütülmüştür. Ancak bu ders, 2018-2019 eğitim-öğ- 
retim yılında güncellenen İlköğretim Matematik Öğretmenliği Lisans Programında seçmeli bir ders olarak gözükmemektedir. Buna karşılık, "Sayılar ve İşlemler Öğretimi”, "Cebir Öğretimi”, "Geometri ve Ölçme Öğretimi”, "Matematik Öğretiminde Etkinlik Geliştirme" ve "Matematik Öğretiminde Materyal Tasarımı" gibi alan eğitimi derslerinde kâğıt katlama yöntemi kullanılarak öğretmen adaylarının çeşitli origami etkinlikleri geliştirmelerine ve bunları öğretim uygulamalarında kullanmaları yoluna gidilebilir. Böylelikle Matematik Eğitimi dersleri farklı öğretim strateji/yöntem/tekniklerle, somut model ya da materyallerle zenginleştirilerek uzamsal beceriler geliştirilebilir, uzaysal/görsel zekâ uygulamalarına katkılar sağlanarak daha iyi geoemetri öğrenebilen bireyler yatiştirilebilir. Uzaysal/görsel zekâ bir bireyin görsel/uzaysal dünyayı algılaması, anlamdırması ve bunlardan çıkardığı sonuçlara dayalı işlemler yapabilmesi demek olduğundan; biçime, sekile, boşluğa, renge, çizgiye karşı duyarlıdır ve boşluğu zihinde canlandırabilir, model kullanarak uygulamalar yapabilir (Gardner, 1993; Armstrong, 2009). Bu çalışma, "Kâğıt Katlama Yöntemi ile Matematik-Origami" dersinin Türkiye' deki öğretmen yetiştiren kurumlar olan tüm Eğitim Fakültelerinin lisans programına, ilkokul ve ortaokul öğretim programlarına konulması anlamında dikkatleri çekebilir. Öte yandan 2018 yılında güncellenen Ortaöğretim Matematik Dersi Öğretim Programinda da, "özel dörtgenlerin açı, kenar, köşegen ve alan özelliklerini açıklayarak problemler çözer" kazanımında origami kullanılarak uygulamalar yapılabileceği yer almaktadır (MEB, 2018b). Bu durum, origami ile öğretim uygulamalarının ortaöğretimde de geometri konularına entegre edilebileceğinin bir göstergesidir.

Mevcut çalışmada origami uygulamalarıyla; "Çokgenleri isimlendirir, oluşturur ve temel elemanlarm tanır, açılarına ve kenarlarnna göre üçgenler oluşturur, oluşturulmuş farklı üçgenleri kenar ve açı özelliklerine göre sımflandırır, üçgen ve dörtgenin iç açılarının ölçüleri toplamın belirler ve verilmeyen açıyı bulur" kazanımlarının öğretimi yapılmıştır. Bu bağlamda öğretmen, öğretmen adayı ve öğrencilerin geometrik şekilleri tanıma, tanımlama ve örneklendirmede kolaylık yaşaması için origami tabanlı öğretim uygulamalarından yararlanmaları sağlanabilir. Son olarak bu çalışma, öğretmen adaylarının lisansta aldıkları bazı Alan Eğitimi ve "Öğretmenlik Uygulaması" derslerinde, öğretmenlerin matematik derslerinde, geometri ve diğer öğrenme alanınlarının öğretim uygulamalarını zenginleştirmek adına origami etkinlikleriyle yapılandırılan sınıf ortamları tasarlamalarına rehberlik edebilir. 


\title{
EXTENDED ABSTRACT
}

\section{Contributions and Challenges of Origami Based Teaching Practices to Prospective Teachers: Triangle and Quadrangles}

\author{
Mihriban Hacısalihoğlu Karadeniz \\ Giresun University
}

The aim of this study is to reveal the problems faced by teacher candidates and their contributions in the process of applying origami-based teaching practices to secondary school students in the teaching of the subject "Triangle and Quadrants". For this purpose, answers to the following questions were sought:

1. What are the difficulties that teacher candidates face in classical origami based teaching practices?

2. What are the opinions of the preservice teachers regarding the contributions of classical origami based teaching practices to students?

3. What are the contributions of classical origami based teaching practices to prospective teachers?

In this study, by preparing the pre-service teachers various classical origami activities for geometry teaching; The study is an explanatory case study, as it is intended to be implemented in the real environment, to describe what it is and their impact on the target group, and to explicitly reveal a particular situation with limits. The participants of the research were conducted with 38 pre-service teachers who took the "Paper Folding Method Mathematics" course in the 2nd grade of the mathematics education of a state university in the eastern Black Sea region in the fall semester of the 2017-2018 academic year through the purposeful sampling methods, easily accessible case sampling.

In the study, various classical origami models were prepared for the participants within the scope of "Mathematics with Paper Folding Method". They were asked to write a report in accordance with the concepts to be taught. While the candidates are designing the reports; they are free to choose the learning area, sub-learning area, grade level, achievements, methods/techniques, equipment / materials and the course of the lesson. The data were collected by using the "Interview Form for Teacher Candidates" consist- 
ing of open-ended questions prepared by the researcher and the "Classic Origami Report" prepared by the candidates. The participants were asked to report in detail all the steps regarding the subject they will teach with origami. In the interview form, the participants were asked to give answers regarding the contributions provided by the teaching of origami and the problems they encountered in the process.

When the problems encountered in origami based teaching practices are considered in terms of participants; Difficulties such as "making students origami model, giving instructions while making the model, implementing it after making the model, providing classroom control, teaching geometry and having problems arising from insufficient geometry knowledge" are among the results obtained. Teachers who will fulfill this task in the future will be accustomed to such practices with origami based teaching practices.

Considering the student size among the problems faced by the participants in the applications; Problems such as "students' difficulty in teaching due to lack of readiness, they do not want to practice, some students get bored very quickly and think that they cannot do the questions addressed in practice" have arisen. In this context, in order to overcome the difficulties that students experience in mathematics and geometry, students may be made to practice with origami from time to time to better understand the subject.

When the problems experienced by participants in origami based teaching, practices are examined in terms of time; the findings of "loss of time in practice due to the inability to use time effectively and low levels of readiness of students" were reached. Preparing a classic origami model is a shorter practice than preparing a fragmented origami model (Hacisalihoğlu Karadeniz, 2017). However, it suggests that there is a problem about time because pre-service teachers are not accustomed to having such practices in the classroom environment in secondary school. It can be said that this is a normal situation for the prospective teacher who is studying in the second grade.

When the contributions of origami based teaching practices to students are considered in terms of the curriculum; "Learning outcomes and geometry in the program, learning the content of the course, learning to make origami using paper folding method, seeing different methods/techniques, using concrete models and tools, developing the language of mathematics, valuing mathematics, spatial and 2-3 dimensional thinking, mathematical developing the thinking-problem solving-reasoning skill". In line with these results, it can 
be said that teacher candidates perceive students' academic skills better. Recently, mathematics teaching is included with this method (Yuzawa ve Bart, 2002; Mastin, 2007; Çakmak, 2009; Golan ve Jackson, 2010; Hacısalihoğlu Karadeniz, 2017,2018).While the student is trying to make origami, point, line, angle, deltoid, bisector, symmetry axis, square, triangle etc. has to form geometric concepts on the model. These concepts form Euclidean geometry, so the student dealing with origami can learn Euclidean geometry while folding the paper.

When the contribution of origami based teaching practices to students is considered in terms of the curriculum; It is among the results that origami contributes to improving the language of mathematics. In the professional development standards of mathematics teachers of NCTM (1991), it is emphasized that teachers should ask students to explain their mathematical ideas in writing / verbally, and when and how they will relate mathematics to students' ideas. Therefore, learning environments that support the development of students' mathematical communication and language skills should be designed by teachers (Kotsopoulos, 2007).

When the contributions of origami based teaching practices to secondary school students are considered in terms of social-emotional development area; the codes of "learning with fun, drawing attention and attention, and wondering, loving mathematics" were obtained. It can be said that it is an effective educational tool since the student perceives origami as a game (MEB, 2011).

When the contributions of origami based teaching practices to secondary school students are considered in terms of psychomotor development area, the participants; It is seen that students express that they contribute to their psychomotor skills such as paper folding, cutting, painting and pasting. It is stated in the program that the concrete model, material and millimetric, dotted and isomeric papers included in the process contribute effectively, creating geometric shapes, mathematical relationships, patterns, item figures by folding paper, contributing to the development of students' cognitive-social and affective-psychomotor skills (MEB, 2009). Considering the contributions of origami based teaching practices to prospective teachers; we see that it is classified as "personal and professional development".

Participants' gains regarding professional development; "Learning to use the paper folding method, making origami and making-making the lesson interesting, preparing for the lesson-gaining professional experience, preparing a lesson plan-learning to use various methods/techniques, associating 
mathematics with daily life, getting to know the student, having experience, teaching rehearsal do not do it". The contributions of the participants regarding personal development are; It is seen that he is described as "learning to be patient and tolerant, checking his excitement in front of the class, seeing my deficiencies, learning to achieve class control and passing the lesson".

This study "Mathematics with Paper Folding Method" course of the undergraduate program of the Faculty of Education that all teacher training institutions in Turkey may be attracted attention in terms of the primary and secondary curriculum. On the other hand, in the updated Secondary Mathematics Curriculum, applications can be made using origami in the acquisition of "solving problems by explaining the angle, edge, diagonal and area properties of special quadrants" (MEB, 2018b). In this study, with origami applications; The teaching of "names, creates and recognizes the basic elements of polygons, creates triangles according to their angles and edges, classifies the different triangles according to their edge and angle properties, determines the sum of the dimensions of the inner angles of the triangle and quadrilateral and finds the angle that is not given". Finally, this study can guide teacher candidates to design classroom environments structured with origami activities to enrich the teaching practices of geometry and other learning areas in "Teaching Practice" lessons, teachers' mathematics lessons.

\section{Kaynakça / References}

Akan-Sağsöz, D. (2008). Ilköğretim 6. Sinıftaki kesirler konusunun origami yardımıyla öğretimi.Yayımlanmamış yüksek lisans tezi, Atatürk Üniversitesi, Fen Bilimleri Enstitüsü, Erzurum.

Akayuure, P., Asiedu-Addo, S. K., ve Alebna, V. (2016). Investigating the effect of Origami instruction on pre-service teachers' spatial ability and geometric knowledge for teaching. International Journal of Education in Mathematics, Science and Technology, 4(3), 198-209.

Armstrong, T. (2009). Multiple intelligences in the classroom. Alexandria: ASCD Virginia.

Arıc1, S. (2012). The effect of Origami-based instruction on spatial visualization, geometry achievement and geometric reasoning of tenth-grade stdents. Master's thesis. Boğaziçi University, Istanbul, Turkey. 
Aricı, S. ve Aslan-Tutak, F, (2015). The effect of origami-based instruction on spatial visualization, geometry achievement, and geometric reasoning. International Journal of Science and Mathematics Education, 13(1), 179-200.

Işıksal-Bostan, M. ve Şahin, E. (2013). The development of belief scale about using Origami in mathematics education. Hacettepe University Journal of Education, 28(2), 44-57.

Baki, A. (2008). Kuramdan uygulamaya matematik eğitimi (4. Bask1). Ankara: Harf Eğitim Yayıncllık.

Baki, A. (2018). Matematiği öğretme bilgisi. Ankara: Pegem Akademi Yayınevi. Boakes, N. (2008). Origami-mathematics lessons: Paper folding as a teaching tool. Mathidues, 1(1), 1-9.

Boakes, N. (2009). Origami instruction in the middle school mathematics classroom: Its impact on spatial visualization and geometry knowledge of students. Research in Middle Level Education Online, 32(7), 1-12.

Boz, B. (2015). İki boyutlu kâğıtlardan üç boyutlu origami küpüne yolculuk. Araştırma Temelli Etkinlik Dergisi (ATED), 5(1), 20-33.

Brady, K. (2008).Using paper folding in the primary years to promote student engagement in mathematical learning.Proceedings of the 31st Annual Conference of the Mathematics Education Research Group of Australasia M.Goos,77-83.

Cipoletti, B. ve Wilson, N. (2004). Turning origami into the language of mathematics. Mathematics Teaching in the Middle School, 10(1), 26-31.

Chen, K. (2006). Math in motion: Origami math for students who are deaf and hard of hearing. Journal of Deaf Studies and Deaf Education, 11(2), 262-266.

Coad, L. (2006). Paper folding in the middle school classroom and beyond. Australian Mathematics Teacher, 62(1), 6-13.

Cohen, L., Manion, L. ve Morrison K. (2000). Research methods in education (5th Edition). London: Routledge Falmer.

Çakmak, S. (2009). An investigation of the effect of Origami-based instruction on elementary students's spatial ability in matehematic. Yüksek Lisans Tezi, Orta Doğu Teknik Üniversitesi Sosyal Bilimler Enstitüsü, Ankara.

DeYoung, M. J. (2009). Math in the box. Mathematics Teaching in the Middle School, 15(3), 134-141.

Duatepe-Paksu, A. ve Ubuz, B. (2004). Drama temelli geometri ders planının geliştirilmesi ve uygulanması. Eğitimde İyi Örnekler Konferansı'nda sunulan bildiri, Sabancı Üniversitesi, İstanbul.

Duatepe-Paksu, A. (2016). Kâğıt katlama yöntemiyle dörtgenlerin incelenmesi. Araştırma Temelli Etkinlik Dergisi (ATED), 6(2), 80-88. 
Gardner, H. (1993). Multiple intelligences: The theory in practice. New York: Basic Books. Georgeson, J. (2011). Fold in Origami and unfold math. Mathematics Teaching in Middle School, 16(6), 354-361.

Golan, M. ve Jackson, P. (2010). Origametria: A program to teach geometry and to develop learning skills using the art of origami. 06.04.2011 tarihinde http://www.emotive.co.il/Origami/db/pdf/996 golan article.pdf adresinden erişilmiştir.

Gür, H. ve Kobak-Demir, M. (2016). Oyun temelli matematik öğrenme laboratuvarı projesine ilişkin öğretmen adaylarının görüşleri. Necatibey Eğitim Fakültesi Elektronik Fen ve Matematik Ĕ̆itimi Dergisi, 10(1), 415-438.

Hacısalihoğlu Karadeniz, M. (2017). Mathematics teaching via paper folding method. Illköğretim Online. 16(2), 663-692.

Hacısalihoğlu Karadeniz, M. (2018). Kâğıt katlama yöntemi kullanılarak tasarlanan uygulamaların matematik eğitimindeki etkililiği. III. INES Education and Social Science Congress (ESS)'de sunulan bildiri, Alanya, Antalya.

Hacısalihoğlu Karadeniz, M. (2019). Origami tabanlı öğretim uygulamaları: Dik koni ve dik piramit. 4th International Symposium of Turkish Computer and Mathematics Education'de sunulan bildiri, Çeşme, İzmir.

Higginson, W. ve Colgan, L. (2001). Algebraic thinking through origami. Mathematics Teaching in the Middle School, 6(6), 343-349.

Kabael, T. ve Ata Baran, A. (2016). Matematik öğretmenlerinin matemaiksel iletişim becerilerinin gelişimine yönelik farkındalıklarının İncelenmesi. Illöğretim Online, 15(3), 868-881.

Kotsopoulos, D. (2007). Mathematics discourse: It's like hearing a foreign language. Mathematics Teacher, 101(4), 301-305.

Mastin, M. (2007). Story telling origami mathematics. Teaching Children Mathematics, 14(4), 206-212.

Milli Eğitim Bakanlığı [MEB]. (2009). Ilköğretim matematik dersi (6-8. Sınıflar) öğretim programı. Ankara: Talim Terbiye Kurulu Başkanlığı.

Milli Eğitim Bakanlı̆̆1 (2011). Ortaöğretim geometri (9, 10, 11 ve 12. sinıflar) dersi öğretim programı. Ankara: Talim ve Terbiye Kurulu Başkanlığı.

Milli Eğitim Bakanlığ1 [MEB]. (2013). Ortaokul matematik dersi (5-8. Sinflar) öğretim programı. Ankara: Talim Terbiye Kurulu Başkanlığı.

Milli Eğitim Bakanlığı [MEB]. (2017, 2018a). Matematik dersi öğretim programı (Illkokul ve Ortaokul 1, 2, 3, 4, 5, 6, 7 ve 8. Sinıflar). Ankara: MEB Yayınevi.

Milli Eğitim Bakanlığ [MEB]. (2018b). Ortä̈ğretim matematik dersi (9, 10, 11 ve 12. Sınılar) öğretim programı. Ankara: MEB Yayınevi. 
National Council of Teachers of Mathematics [NCTM]. (1991). Professional Standards for Teaching Mathematics. 11 Haziran 2013 tarihinde URL:http://www.nctm.org/flipbooks/standards/professionalteaching/index.html adresinden erişilmiştir.

National Council of Teachers of Mathematics [NCTM]. (2000). Principles and Standards for School Mathematics. Virginia 2000.

Patton, Q. M. (2002). Practical Evaluation. Thousand Oaks, CA: Sage Publications. Philipp, R. A. (2007). Mathematics teachers' beliefs and affect. F. K. Lester (Ed.), Second handbook of research on mathematics teaching and learning içinde (s. 257-315). Charlotte, NC: Information Age Publishing.

Polat, S. (2013). Origami ile matematik öğretimi. Mustafa Kemal Üniversitesi Sosyal Bilimler Enstitüsü Dergisi, 10(21), 15-27.

Sze,S.(2005). Math and mind mapping: Origami construction. http://www.eric.ed.gov/ERICDocs/data/ericdocs2sq/content storage $01 / 0000019 \mathrm{~b} / 80 / 1 \mathrm{~b} / \mathrm{c} 0 /$ ae.pdf adresinden erişilmiştir.

Tuğrul, B. ve Kavici, M. (2002). Kâğıt katlama sanatı ve öğrenme. Pamukkale Üniversitesi Eğitim Fakültesi Dergisi, 1(11), 1-17.

Yıldırım, A. ve Şimşek, H. (2013). Sosyal bilimlerde nitel araştırma yöntemleri. Ankara: Seçkin Yayıncılık.

Yin, R. K. (2009). Case study research: Design and methods (4th Ed.). Thousand Oaks, CA: Sage.

Yuzawa, M. ve Bart, W. M. (2002). Young children's learning of size comparison strategies: Effect of Origami exercises. The Journal of Genetic Psychology, 163(4), 459-478.

Wares, A. (2013). Appreciation of mathematics through origami. International Journal of Mathematical Education in Science and Technology, 44(2), 277-283.

Wares, A. (2016). Mathematical thinking and origami. International Journal of Mathematical Education in Science and Technology, 47(1), 155-163.

\section{Kaynakça Bilgisi / Citation Information}

Karadeniz Hacısalihoğlu, M. (2020). Origami tabanlı öğretim uygulamalarının öğretmen adaylarına katkıları ve karşılaşılan zorluklar: Üçgen ve dörtgenler. OPUS-Uluslararası Toplum Araştırmaları Dergisi, 15(24), 2584-2614. DOI: 10.26466/opus.651290 